\title{
Clinical study on the effect of Dwiharidra rasakriya pichu in the management of Parikartika (Fissure in ano)
}

\author{
Research Article
}

\section{Neetu Vishwakarma ${ }^{*}$, Srinivasa Kumar $K^{2}$, Nagamani $D^{3}$}

1. PG Scholar, 2. Associate professor, 3. Assistant Professor

Department of Shalya Tantra, SV Ayurvedic College, Tirupati.

\begin{abstract}
Parikartika is one of the most common disorder of ano-rectal diseases. Parikartika resembles with 'fissure in ano' having cutting and burning pain in guda (anus). It is most painful condition affecting the anal region. In Parikartika, the local treatment is such as ointments, Ghrita, Taila and dilatation also known. In the present clinical study the Dwiharidra Raskriya Pichu is taken as external application on fissure (Parikartika).
\end{abstract}

Keywords: Parikartika; Ano-rectal diseases; Fissure in ano; Dwiharidra Raskriya Pichu.

\section{Introduction}

Acharya Sushruta has narrated that the person who does not follow the Aahara Vidhi, and consume Shushka, Viruddha \& Vishtambhi food, he gets Agnidushti (Dyspepsia),(1) which is root cause of all diseases. He further added that nobody should consume food of only one Rasa (Taste) daily.(2) Thus, improper diet, spicy and junk food are responsible for causation of all diseases especially ano -rectal diseases.

Parikartika is one of the most common disorder of ano-rectal diseases. Acharya Sushruta has mentioned the cardinal symptom of Parikartika as sharp cutting and burning pain in Guda. The causative Doshas are Vata and Pitta and the pain predominantly displays a Vatika and Paittika character by the sensation of cutting and burning in ano respectively. (3) Charaka has mentioned the symptom, severe pain in ano while describing Parikartika as a complication of Vamana and Virechana. (4) Fissure in ano is equated with Parikartika mentioned in classics and is manifested as having cutting and burning pain in guda (anus). An anal fissure is an elongated ulcer in the long axis of the lower anal canal. (5) It is most painful condition affecting the anal region. $90 \%$ of fissure in ano occur in the posterior part of anal canal and $10 \%$ anteriorly. It is initiated by hard stool causing a crack which result painful defecation. Due to pain, spasm of internal anal sphincter takes place which makes constipation worse resulting in a chronic fissure. (6)

In Parikartika the treatment is Basti Karma and some oral medications given by acharya Charaka (7) and Sushuruta (8). Most of the Basti are prepared

*Corresponding Author:

Neetu Vishwakarma

PG Scholar, Department of Shalya Tantra,

SV Ayurvedic College, Tirupati

Andhra Pradesh, India. 517507

Email Id - neetuvish5@gmail.com in Ghrita, Taila and milk with the help of other ingredients as per need. Most of the ingredients, used in Basti Karma, are Vata Pitta Shamaka, Vrana Shodhaka and Vrana Ropaka. Systemic oral formulations correct the gastrointestinal disorders by laxative action and increase the digestion by Agnideepana and Aamapachana. The role of ointments, Ghrita preparations, Taila and dilatation are known in cases of Parikartika.

In the present clinical study the Dwiharidra Rasakriya Pichu is taken as external application on fissure (Parikartika). The idea of this study is taken from Dwivraniya Chikitsa A dhyaya of Sushrut Samhita. Acharya Sushruta told that Raskriya with Dwiharidra resorte the healing of an ulcer. (9)

\section{Aims and Objectives}

To evaluate the role of Dwiharidra Raskriya Pichu in the management of Parikartika (Fissure-inano).

\section{Materials and Methods}

The present study was carried out on 20 patients with anal fissure, selected from the O.P.D. of Department of Shalya tantra, S. V. Ayurvedic College $\&$ hospital, Tirupati.

\section{Inclusive criteria:}

- Patients irrespective of sex, religion, occupation \& economic status.

- Patients in between the age group of 18 to 60 years.

- Patients without systemic diseases like Diabetes and Hypertension, are included in the study.

Exclusive criteria:

- Patients associated with Ulcerative Colitis, Syphilis, Crohn's diseases, Tuberculosis and Carcinoma of rectum and anal canal.

- Patients with infectious diseases like HIV \& HbsAg. etc.

- Patients with complicated conditions like Diabetes and Hypertension. 


\section{Diagnostic Criteria}

The patients are diagnosed on the basis of history, signs \& symptoms and physical examination of Parikartika (Fissure-in-ano). The diagnosis is made after following examination-

\section{Inspection}

- The perianal skin color is inspected for any discoloration and presence of scratches over there which are suggestive Pruritus ani.

- Presence of an ulcer in the long axis of anal canal and external sentinel tag.

- Presence of external piles.

\section{Palpation}

Digital per rectal examination is carried out with $2 \%$ Xylocaine jelly to assess the sphincter tone in accordance with tolerance of pain.

\section{Laboratory Investigations}

- Routine Haemogram

- Fasting Blood Sugar, Postprandial Blood Sugar

- Human immunodeficiency virus, Venereal Disease Research Laboratory test, Hepatitis B Surface antigen.

- Urine analysis- Albumin, Sugar \& Microscopic.

Advice:

- Sitz bath with luke warm water mixed with 1 tsp Triphala twice a day indicated to maintain local hygene.

\section{Preparation of Dwiharidra Raskriya}

Dwiharidra Raskriya contains Daruharidra and

Haridra. Daruharidra bark and Haridra rhizome are procured. The Daruharidra is crushed into coarse powder and then mixed 1 part of Daruharidra bark coarse powder thoroughly with 16 parts of water in a stainless steel container and then continuous mild heat is applied until it is reduced to one-fourth of its initial quantity. In the same way, Kwatha of Haridra is also prepared. During the heating process, continuous stirring is done to facilitate the evaporation and avoid any deterioration or sedimentation. After a desirable reduction in volume is achieved, both the Kwathas are filtered through single folded cotton cloth and collected in a separate vessel. Then, both the Kwathas are mixed and then boiled again over mild fire on a gas stove. As the water evaporates, the viscosity of the extract increases which resulting in Ghana form. This solid mass (Ghana) is collected and dried at $50^{\circ} \mathrm{C}$ in a hot air oven for 10 hours. The dried mass is grinded. The formulation is then made in paste form with the help of Siktha Tail.

\section{Procedure-}

Patient is kept in lithotomy position. The perianal area is cleaned with aseptic solution and then Dwiharidra Raskriya Pichu applied over the fissure in ano once a day for 14 days.
Assessment Criteria

The Parameters for the present study are -

To evaluate the efficacy of the treatment on the basis of the relief in the sign and symptoms both before and after treatment was taken for consideration. The details of parameters were narrated below.

\section{Subjective}

1. Pain:-

- Intensity of pain on 10 point scale was recorded according to the patient's self-assessment.

- Duration of pain after defecation in minutes was recorded according to the patient's self-assessment.

\section{Burning Sensation:-}

- Intensity of burning sensation on 10 point scale was recorded according to the patient's self-assessment.

- Duration of burning sensation after defecation in minutes was recorded according to the patient's selfassessment.

3. Streak of fresh blood:-

Grading was done as

0 - Absent

1- Present

4. Tenderness-

Grading was done as

0 - Absent

1 -Present

5.Itching-

Grading was done as

0 - Absent

1 - Present

\section{Objective parameters}

1. Assessment of sphincter spasm:-

Gradation of sphincteric spasm was done on the basis of digital examination-

0 - Normal - No tightness of anal sphincter

1 - Mildly - Tight anal sphincter present

2 - Moderate - Due tightness of anal sphincter

3 - Severe - Digital examination not possible due

\section{Length of Fissure -} to tightness of anal sphincter.

Grading was done on the basis of length of Fissure in Ano as
0 - No Fissure
$1-1 \mathrm{~mm}$
2- $2 \mathrm{~mm}$
3- $3 \mathrm{~mm}$
4- $4 \mathrm{~mm}$
5- $5 \mathrm{~mm}$
6- $>5 \mathrm{~mm}$

\section{Statistical analysis}

All information based on various parameters were gathered and analyzed statistically in terms of Mean (X), Standard Deviation (SD), Standard Error $(\mathrm{SE})$, ' $\mathrm{t}$ ' test and Probability ' $\mathrm{P}$ ' as-

$$
\begin{aligned}
& \mathrm{P}<0.05 \text { Significant } \\
& \mathrm{P}<0.001 \text { Highly Significant } \\
& \mathrm{P}>0.05 \text { Non-Significant }
\end{aligned}
$$

The result will be analyzed with the help of $5 \%$ and $1 \%$ level of significance. 
Table No. 1: Effect of treatment on patients

\begin{tabular}{|c|c|c|c|c|c|c|c|c|c|c|}
\hline \multirow{2}{*}{ Parameters } & \multicolumn{2}{|c|}{ Mean } & \multirow{2}{*}{$\begin{array}{l}\% \text { of } \\
\text { relief }\end{array}$} & \multicolumn{2}{|c|}{ S.D. } & \multicolumn{2}{|c|}{ S.E. } & \multirow{2}{*}{ ' $t$ ' } & \multirow{2}{*}{$\mathbf{P}$} & \multirow{2}{*}{ Significant } \\
\hline & B.T. & A.T. & & B.T. & A.T. & B.T. & A.T. & & & \\
\hline Pain & 8.50 & 0.65 & 92.35 & 2.19 & 1.31 & 0.49 & 0.29 & 13.4966 & $<0.001$ & $\begin{array}{c}\text { Highly } \\
\text { Significant }\end{array}$ \\
\hline $\begin{array}{l}\text { Burning } \\
\text { Sensation }\end{array}$ & 6.60 & 0.50 & 92.42 & 3.17 & 1.19 & 0.71 & 0.27 & 9.1254 & $<0.001$ & $\begin{array}{c}\text { Highly } \\
\text { Significant }\end{array}$ \\
\hline $\begin{array}{c}\text { Streak of } \\
\text { blood }\end{array}$ & 0.70 & 0.00 & 100.00 & 0.47 & 0.00 & 0.11 & 0.00 & 6.6583 & $<0.001$ & $\begin{array}{c}\text { Highly } \\
\text { Significant }\end{array}$ \\
\hline Tenderness & 1.00 & 0.60 & 40.00 & 0.00 & 0.50 & 0.00 & 0.11 & 3.5590 & $<0.05$ & Significant \\
\hline Itching & 0.60 & 0.00 & 100.00 & 0.50 & 0.00 & 0.11 & 0.00 & 5.3385 & $<0.001$ & $\begin{array}{c}\text { Highly } \\
\text { Significant }\end{array}$ \\
\hline $\begin{array}{c}\text { Sphincter } \\
\text { Tone }\end{array}$ & 2.25 & 0.20 & 91.11 & 0.97 & 0.41 & 0.22 & 0.09 & 8.7308 & $<0.001$ & $\begin{array}{c}\text { Highly } \\
\text { Significant }\end{array}$ \\
\hline $\begin{array}{c}\text { Length of } \\
\text { Fissure } \\
\text { (in mm.) } \\
\end{array}$ & 10.00 & 2.33 & 77.00 & 5.26 & 2.27 & 1.18 & 0.51 & 7.7388 & $<0.001$ & $\begin{array}{l}\text { Highly } \\
\text { Significant }\end{array}$ \\
\hline Overall effect & 4.23 & 0.61 & 3.62 & 4.02 & 0.80 & 1.52 & 0.30 & 2.7890 & $<0.05$ & Significant \\
\hline
\end{tabular}

Effect on Pain (Guda Pida): It is reported that initial mean of Guda Pida is 08.50 and after treatment it reduced to 00.65 . This relief is statistically Highly Significant $(\mathrm{P}<0.001)$.

Effect on Burnning sensation (Guda Daha): Table shows that before starting the treatment, mean gradation of Guda Daha is 06.60 and after the treatment it is reduced to 0.50 . This reduction is statistically Highly Significant $(\mathrm{P}<0.001)$.

Effect on Streake of blood (Rakta Srava): Its initial mean score is 07.00 , which reduced to 00.00 after the treatment. This improvement is statistically Highly Significant $(\mathrm{P}<0.001)$.

Effect on Tenderness: In present study, it is observed that the mean gradation of tenderness before treatment is 01.00 which decreased to 00.60 after the treatment, which is statistically significant $(\mathrm{P}<0.05)$.

Effect on Itching (Kandu): It is observedthat the mean score of Kandu before the treatment is 00.60 and after the completion of the course, it decreased to 00.00. This relief is statistically Highly Significant $(\mathrm{P}<0.001)$.

Effect on Sphincter Tone: The present study illustrates that initial mean of sphincter tone is 02.25 which is reduced to 0.20 after treatment. The relief is statistically Highly Significant $(\mathrm{P}<0.001)$.

Effect on Fissure length: The initial mean score of the fissure length is 10.00 , which is reduced to 02.33 after the treatment. The relief is statistically Highly Significant $(\mathrm{P}<0.001)$.

Overall effect: In present study, it was observed that the mean score of overall effect before the treatment was 4.23 and after the completion of the course, it decreased to 0.61 . This relief is statistically significant $(\mathrm{P}<0.05)$.

\section{Discussion and Conclusion \\ Discussion}

Probable mode of action of Dwiharidra Raskriya-

In the present study Dwiharidra Rasakriya is taken for the treatment of Parikartika. The ingredients of
Dwiharidra Rasakriya are Haridra and Daruharidra. Haridra has Kusthaghna, Krimighna and Kandughna properties as described by Charaka, hence it can be attributed to check wound infection and itching. Similarly Daruharidra has Arshoghna, Kandughna and Lekana property as described by Charaka and it is attributed to check bacterial growth and promote wound healing.(10)

Haridra is the drug having Katu, TiktaRasa; RukshaGuna and Daruharidra is having Tikta, Kashaya Rasa; Laghu, RukshaGuna. Katu Rasa is capable to reduce inflammation and itching, Tikta Rasa is capable to reduce itching and burning sensation and Kashaya Rasa is capable of healing and anticoagulant. Ruksha Guna is anticoagulant and Laghu Guna is wound healing. Hence Dwiharidra Rasakriya is capable to reduce inflammation, itching, bleeding, burning sensation and improve healing which are the cardinal symptoms of fissure.(11)

\section{Relief in Symptoms of Parikartika}

Intensity of Pain: It is reported that initial mean of intensity of pain is 8.50 and after treatment it reduced to 0.65. This $92.35 \%$ relief are statistically Highly Significant $(\mathrm{P}<0.001)$ and $(\mathrm{t}=13.4966)$.

Intensity of Burning sensation: It is reported that initial mean of intensity of burning sensation is 6.60 and after treatment it reduced to 0.50 . This $92.42 \%$ relief are statistically Highly Significant $(\mathrm{P}<0.001)$.

Streak of blood: In this study, it is observed that all patients $(100 \%)$ have got complete relief within 7 days and no bleeding is found during follow up period.

Tenderness: Its initial mean score is 1.00 and after treatment it reduced to 0.60 . This $40.00 \%$ relief are statistically Highly Significant $(\mathrm{P}<0.001)$.

Itching: In this study, it is observed that all patients $(100 \%)$ have got complete relief from itching within 7 days during treatment and itching is not found in any patient during follow up period.

Sphincter Tone: It reported that initial mean of 
Sphincter tone is 2.25 and after treatment it reduced to 0.20 . This $91.11 \%$ relief are statistically Highly Significant $(\mathrm{P}<0.001)$.

Size of Fissure: Its initial mean score is 10.00 and after treatment it reduced to 2.33 . This $77.00 \%$ relief are statistically Highly Significant $(\mathrm{P}<0.001)$.

Overall effect: In present study, it was observed that the mean score of overall effect before the treatment was 4.23 and after the completion of the course, it decreased to 0.61 . This relief is statistically significant $(\mathrm{P}<0.05)$.

\section{Conclusion}

It can be concluded that the Dwiharidra Raskria Pichu application is most effective treatment for fissure in ano. It controle streak of blood and itching; modality effective for pain, burning sensation and sphictor spasm and less effective in controlling tenderness, hence we can conclude that this medicine is very effective in Parikartika (Fissure in ano). One advantage of this treatment is that patients can be treated at O.P.D. level.

Acknowledgement: The authors are thankful to Dr. N.T.R. University Of Health Sciences, Vijayawada, A. $\mathrm{P}$., for their support to conduct the said research work.

\section{References}

1. Kaviraja Ambikadutta Shastri. Sushruta Samhita of Maharshi Sushruta vol 1. Chaukhambha Sanskrit Sansthan; Varanasi; 2010. 287p.

2. Kaviraja Ambikadutta Shastri. Sushruta Samhita of Maharshi Sushruta vol 1. Chaukhambha Sanskrit Sansthan; Varanasi; 2010. 286p.
3. Kaviraja Ambikadutta Shastri. Sushruta Samhita of Maharshi Sushruta vol 1. Chaukhambha Sanskrit Sansthan; Varanasi; 2010. 187p.

4. Kasinatha Sastri and Dr. Gorakha Natha Chaturvedi. Charaka Samhita (Moolamatra). Chaukhamba academy; Varanasi; Reprint: 2004, 1028p.

5. Baily and love's Short Practice of surgery. Edited by R.C.G. Russell, Norman S. Williams \& Christopher J.K. Bulstrode. $23^{\text {th }}$ edition; Arnold, a member of Hodder Headline Group, London; 2000. 1125p.

6. Rajgopal Shenoy K. Manipal Manual of Surgery. Second edition. CBS Publishers \& Distributors; New Delhi; 2005. 531p.

7. Pandit Kashinath Shastri. Charaka Samhita of Agnivesha. vol 1. Sutrasthan 30/26. Chaukhambha Sanskrit Sansthan; Varanasi; 2009. 1028p.

8. Kaviraja Ambikadutta Shastri. Sushruta Samhita of Maharshi Sushruta vol 1. Chaukhambha Sanskrit Sansthan; Varanasi; 2010. 187p.

9. Kaviraj Kunjalal Bhishagratna. Sushrut Samhita. Edited by Dr. Laxmidhar dwivedi. Chaukhamba Krishnadas academy; Varanasi; $3^{\text {rd }}$ edition; 2007. 296-297p.

10.Pandit Kashinath Shastri. Charaka Samhita of Agnivesha. vol 1. Sutrasthan 30/26. Chaukhambha Sanskrit Sansthan; Varanasi; 2009. 72-82p.

11. Chunekar KC. Bhavaprakash Nighantu. Chaukhambha Bharati Academy; Varanasi; 2013. 111-115p.

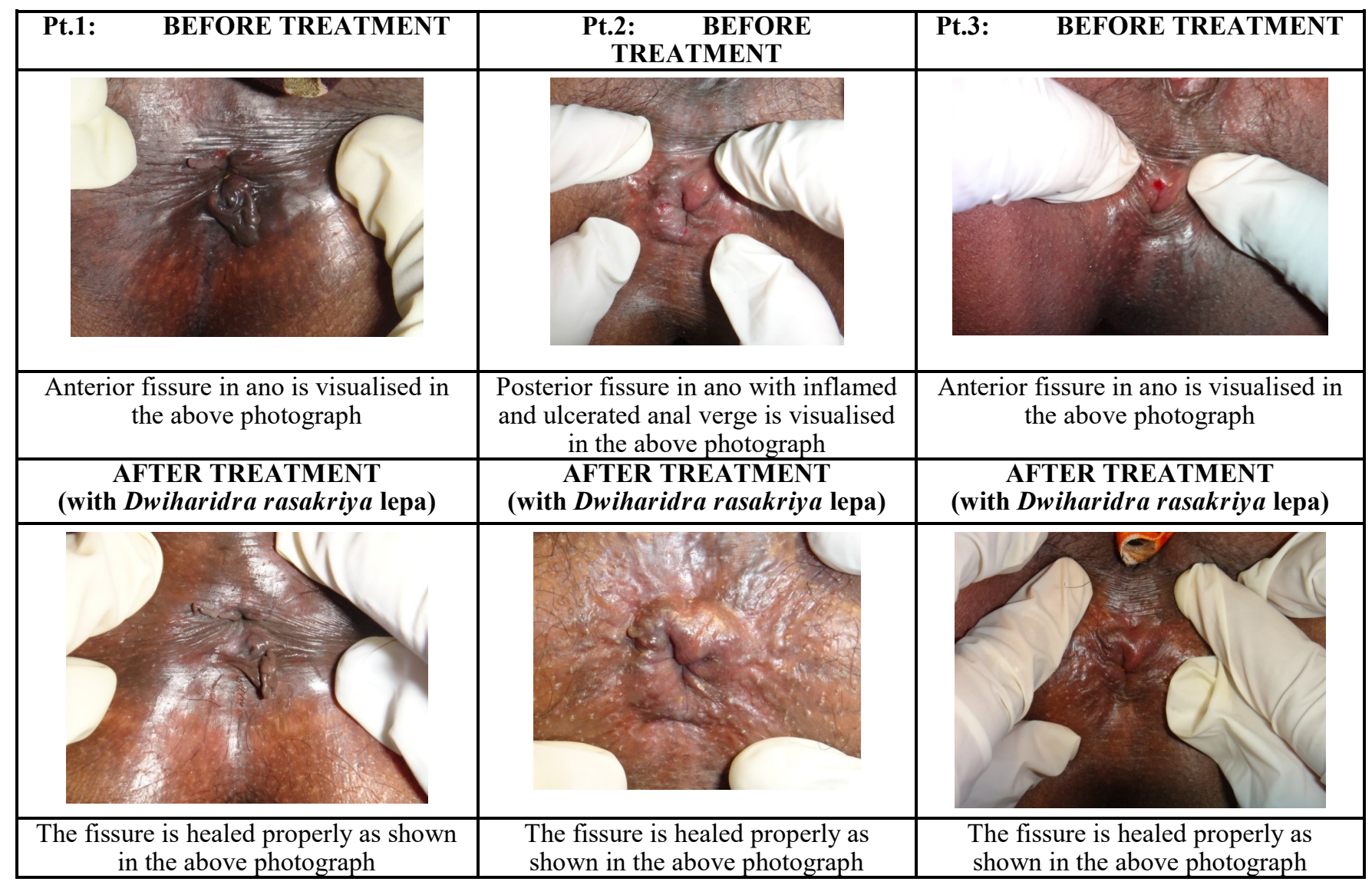

$* * * * *$ 